\title{
СОЦИОЛОГИЯ
}

И СОЦИАЛЬНЫЕ ТЕХНОЛОГИИ

DOI: https://doi.org/10.15688/lp.jvolsu.2017.3.9

UDC 316.75:2

LBC 60.563 .05

\section{RELIGIOUS POLICIES OF THE SECULAR STATE IN TERMS OF RELIGIOUS DIVERSITY}

\author{
Elena M. Miroshnikova \\ Leningrad State University named after A.S. Pushkin, Saint Petersburg, Russian Federation
}

Olga I. Sgibneva

Volgograd State University, Volgograd, Russian Federation

\begin{abstract}
The authors substantiate the need for a clear strategy of state religious policy in Russia drawing on contemporary sociological studies conducted in Eastern and Central Europe, in several other countries. Many of these countries as the Russian Federation are multi-religious. For analysis the authors chose the results of sociological research carried out in 2013-2017 by the two major international research centres: Global Restrictions on Religion Rise Modestly in 2015, Reversing Downward Trend (Pew Research Center); Religious Belief and National Belonging in Central and Eastern Europe (Pew Research Center); Promoting Religious Freedom and Peace through Cross-Cultural Dialogue (Italian Institute for International Political Studies - ISPI). The results of sociological studies show that in modern conditions the religious factor increasingly affecting social, economic, political and cultural spheres of society, its conflictogenity potential is manifested where there is no settlement of interreligious and Church-state relations. In countries with high religious restrictions and religious intolerance is increasing the level of social tension, declining economic performance, falling innovation activity. A dangerous trend of rising religious restrictions has been fixed by sociologists since 2015 . Further dynamics of religious oppression and restrictions may become a serious brake on development. Under these conditions there is the need for a dialogue, search of ways of peaceful coexistence in religious diversity for what thought-out government religious policy is important where a speial role is casted to education, including religious one.

The experience of countries characterized by religious diversity shows the positive potential of the cooperative nodel of relations of the secular state and religious organizations. However in Russia there have been created the basic $\vec{\sim}$ preconditions for its formation. Development of state religious policy is an important condition of harmonization of relations between the state and religions, strengthening of state security of the country and its civilizational identity.

Key words: religious policy, freedom of conscience, freedom of religion, social intolerance, tolerance, dialogue, state-confessional relations.

УДК $316.75: 2$

ББК 60.563 .05

РЕЛИГИОЗНАЯ ПОЛИТИКА СВЕТСКОГО ГОСУДАРСТВА В УСЛОВИЯХ РЕЛИГИОЗНОГО МНОГООБРАЗИЯ
\end{abstract}

\section{Елена Михайловна Мирошникова}

Ленинградский государственный университет им. А.С. Пушкина, г. Санкт-Петербург, Российская Федерация 


\title{
Ольга Ивановна Сгибнева
}

\author{
Волгоградский государственный университет, г. Волгоград, Российская Федерация
}

Аннотация. Авторы обосновывают необходимость четкой стратегии государственной религиозной политики в России, опираясь на современные социологические исследования, проведенные в странах Восточной и Центральной Европы, в ряде других стран. Многие из них, как и Российская Федерация, являются многоконфессиональными. Для анализа авторы выбрали результаты социологических исследований, проведенных в 2013-2017 гг. двумя крупными международными исследовательскими центрами: Global Restrictions on Religion Rise Modestly in 2015, Reversing Downward Trend (Pew Research Center); Religious Belief and National Belonging in Central and Eastern Europe (Pew Research Center); Promoting Religious Freedom and Peace through Cross-Cultural Dialogue (Italian Institute for International Political Studies - ISPI). Результаты социологических исследований свидетельствуют, что в современных условиях религиозный фактор все активнее влияет на социальную, экономическую, политическую и культурную сферы общества, его конфликтогенность проявляется там, где отсутствует урегулированность межрелигиозных и государственно-конфессиональных отношений. В странах с высоким уровнем религиозных ограничений и религиозной нетерпимости растет уровень социальной напряженности, снижаются показатели экономической деятельности, падает инновационная активность. Опасная тенденция роста религиозных ограничений фиксируется социологами с 2015 года. Дальнейшая динамика религиозных притеснений и ограничений может стать серьезным тормозом развития. В этих условиях необходим диалог, поиск путей мирного сосуществования в религиозном многообразии, для чего важна продуманная государственная религиозная политика, в которой особая роль отводится образованию и просвещению, в том числе религиозному.

Опыт стран, для которых характерно религиозное многообразие, показывает позитивный потенциал кооперационной модели отношений светского государства и религиозных организаций. Однако пока в России созданы лишь базовые предпосылки для ее формирования. Выработка государственной религиозной политики является важным условием гармонизации отношений государства и конфессий, укрепления государственной безопасности страны и ее цивилизационной самобытности.

Ключевые слова: религиозная политика, свобода совести, свобода вероисповедания, социальная нетерпимость, толерантность, диалог, государственно-конфессиональные отношения.

В результате длительного исторического развития Россия формировалась как многоконфессиональное государство. С Х в. начинается сложный процесс христианизации русских земель, утверждения православия как официальной религии государства, но этот процесс неразрывно связан с расширением государственного пространства, включением в его состав новых земель со своими национальными традициями и религиями. Христианизация Руси началась еще до разделения церквей (1054 г.), поэтому западное христианство не рассматривалось как чуждое. И хотя в дальнейшем, с учетом военных и политических событий, отношение к католикам неоднократно менялось, католические общины в России действовали все годы ее существования. Первые протестанты появились в нашей стране уже в 20-е гг. XVI в., почти одновременно с распространением протестантских идей в Европе. Продолжительную историю в России имеет иудаизм, к VIII-X вв. относится распространение по территории нашей страны ислама. Эти религии были в Российском государстве и «терпимыми», и «гонимыми», пережили сложные периоды во взаимоотношениях с властью $[6$, с. 99-100]. В Конституции Российской Федерации, принятой в 1993 г., закреплены принципы свободы совести и свободы вероисповеданий, равенства религиозных объединений перед законом $[1$, с. 48,53$]$, и он не может не учитываться в политике государства.

Современный мир переполнен конфликтами и противоречиями. Меняется миропорядок, многие страны стоят перед этнонационалистическими вызовами. И во всех сложных ситуациях в той или иной степени проявляются проблемы национальной и религиозной идентичности. Религиозная нетерпимость, нарушения прав граждан по принципу вероисповедания и, напротив, попытки найти компромисс и выработать приемлемый для всеx modus vivendi - все это играет значительную роль в современном глобальном 
пространстве [12]. Можно вполне согласиться с позицией Российской ассоциации защиты религиозной свободы (РАРС), что сегодня поле реализации свободы совести и свободы вероисповеданий может стать той площадкой, которая позволит России успешно продвигать свои национальные интересы [5, c. 141-142].

Внутри поликонфессиональных стран в современных условиях очень важна грамотная национальная и религиозная политика. В России выработана и утверждена Указом Президента России № 1666 от 19 декабря 2012 г. «Стратегия государственной национальной политики Российской Федерации на период до 2025 г.» [7]. Этому предшествовала глубокая исследовательская и аналитическая работа, встречи с руководителями регионов, руководителями национально-культурных центров и общественных организаций, научным сообществом. В частности, на заседании президиума Госсовета 11 февраля 2011 г. отмечалось, что успешная реализация стратегического курса на модернизацию страны в решающей степени зависит от сохранения и укрепления в обществе гражданского мира, межнационального и межрелигиозного согласия.

Реализация Стратегии государственной национальной политики за прошедшее пятилетие привела к серьезным продвижениям в решении вопросов межнационального взаимодействия, развития национальных культур. В современных условиях остро встал вопрос о выработке государственной стратегии в области религиозной политики. Об этом говорилось на последнем заседании Российской ассоциации защиты религиозной свободы ${ }^{1}$. Необходимость разработки концепции государственной политики в области свободы совести объясняется рядом причин. Главной из них является противоречивая ситуация, связанная с правоприменительной практикой положений Конституции РФ и Федерального закона № 125-Ф3 от 26 сентября 1997 г. «О свободе совести и о религиозных объединениях» [9]: в соответствии с Конституцией в государстве действует принцип отделения религиозных объединений от государства, то есть фактически Основной закон устанавливает отделительную модель государственно-конфессио- нальных отношений, а на практике утвердилась кооперационная модель, предполагающая сотрудничество государства с конфессиями в социально-экономической, культурной и духовно-нравственной сферах. С учетом проблем, которые выявила практика применения Федерального закона «О свободе совести и о религиозных объединениях» (в сферах культуры и образования, социальной и экономической деятельности и др.), Общественная палата России высказывает предложения об обновлении закона 1997 года. В частности, И. Дискин, председатель комиссии Общественной палаты по гармонизации межнациональных и межрелигиозных отношений, предлагает выпустить закон о свободе совести в новой редакции. Новый свод правил, по его мнению, должен отвечать требованиям «новой светскости» и учитывать, что «большинство россиян рассматривают религию сегодня как важный жизненный ориентир... Новая редакция федерального закона должна исходить из ясного понимания новых задач общественного развития и роли религиозных сообществ» [4].

В то же время самая крупная религиозная организация страны - Русская православная церковь (Московский патриархат) стоит на другой позиции. С точки зрения официальных представителей РПЦ, в новом законе нет необходимости, вполне работает ныне действующий с возможностью внесения в него поправок. Председатель синодального отдела по взаимоотношениям Церкви с обществом и СМИ В. Легойда считает на нынешнем этапе эту проблему неактуальной: «Путь поправок есть, он открыт, его никто не отменял, он существует» [4]. Эту точку зрения разделяют и лидеры мусульманского сообщества.

Прошедшие два десятилетия действия Федерального закона с учетом изменений в современном социуме выявили существенные проблемы: как сосуществовать разным религиям в обществе, объявившем религиозную свободу при равенстве всех религий пред законом? Во что выливается религиозная свобода при явном обострении социально-политической ситуации, особенно на фоне распространяющейся тенденции взаимосвязи национальной и религиозной иден- 
тичности? Это серьезный вызов безопасности не только в нашей стране, но и в мире. Естественно, что государство как институт, отвечающий за обеспечение безопасности граждан, да и прочность своей власти, отвечает на негативные проявления, вызванные и религиозными причинами. Доминирующим признаком являются ограничения в отношении религиозной свободы. Эта тенденция характерна сегодня для многих стран мира, о чем свидетельствует ряд социологических исследований последних лет. Их результаты позволяют выявить взаимосвязь и взаимозависимость социально-политических и религиозных процессов, определить наиболее приемлемые модели отношений светских государств и религиозных организаций в условиях современного религиозного многообразия.

Для анализа авторы выбрали результаты социологических исследований, проведенных в 2013-2017 гг. двумя крупными международными исследовательскими центрами ${ }^{2}$ : Global Restrictions on Religion Rise Modestly in 2015, Reversing Downward Trend (Pew Research Center) [10]; Religious Belief and National Belonging in Central and Eastern Europe (Pew Research Center) [13]; Promoting Religious Freedom and Peace through Cross-Cultural Dialogue (Italian Institute for International Political Studies - ISPI) [15].
Так, социологи крупнейшего в мире исследовательского центра по изучению роли религий Pew Research Center (исследование охватило 198 стран) выявили, что «число людей, живущих в странах с высоким уровнем религиозных ограничений и религиозной нетерпимости, достигло фактически 5,9-6 млрд человек, что составляет 78,5 \% всего населения земного шара в 2017 году. Уровень этот увеличился на 1,1 млрд человек с начала исследования этой проблемы в 2009 году. Причем всплеск нетерпимости касается не только слаборазвитых стран, но и страны с ведущей экономикой мира - США. По данным того же источника, уровень религиозной вражды повысился на 3,5 порядка (2009 г. - 2,0; 2014 $5,2 ; 2015-4,2)[10]$ (рис. 1).

Главное, что факт увеличения уровня религиозной вражды неразрывно связан (и тут трудно отдать кому-то пальму первенства) с увеличением социальной нетерпимости, вызванной ограничительными действиями государства по отношению к религии. Вследствие этого сильно страдает и развитие экономики. В странах с низким уровнем ограничений религиозной свободы, редкими проявлениями религиозной вражды выше динамика инновационной политики, экономические показатели в два раза выше, чем в странах со значительными религиозными ограничениями [14, с. 9] (см. рис. 2).

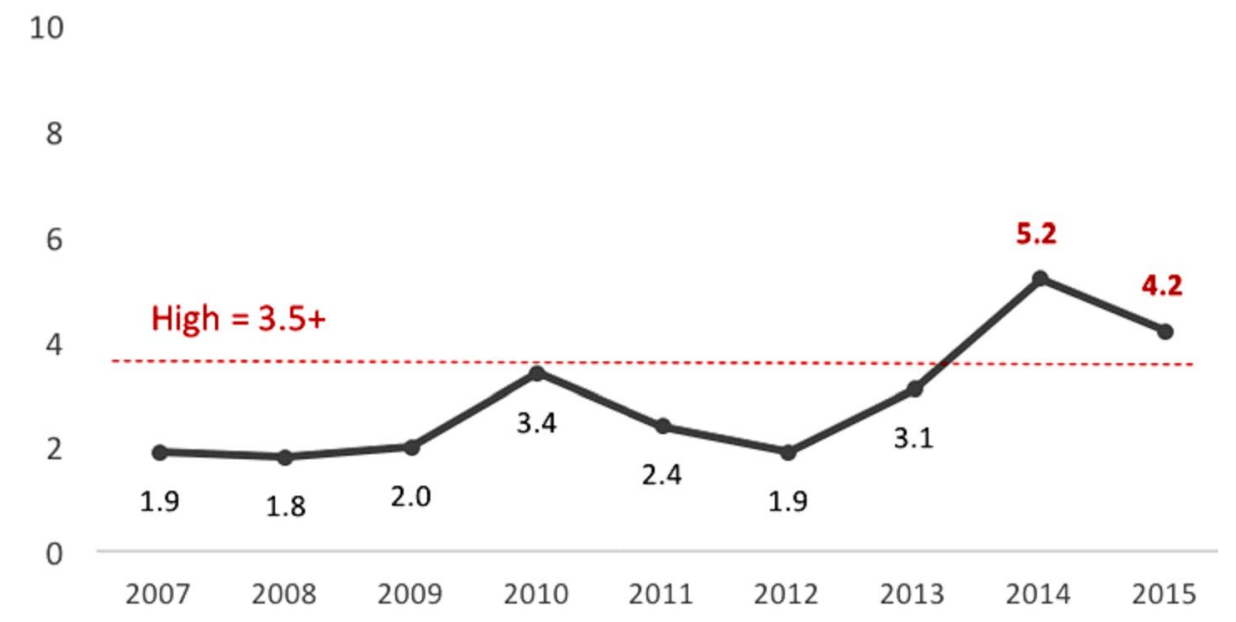

\section{RELIGIOUS FREEDOM \& RFBF BUSINESS FOUNDATION \\ Data: Pew Research Center}

Рис. 1. Изменение уровня религиозной вражды в США (2007-2015 гг.)

Примечание. Источник: [10]. 
Majority of the 12 Pillars of Global Competitiveness Are Stronger* in Countries With LOW Government Restrictions on Religion and LOW Social Hostilities Involving Religion

\begin{tabular}{|c|c|c|}
\hline $\begin{array}{l}\text { Pillar of Global } \\
\text { Competitiveness }\end{array}$ & $\begin{array}{l}\text { Level of Religious } \\
\text { Hostilities or Government } \\
\text { Restrictions on Religion** }\end{array}$ & $\begin{array}{l}\text { Percentage of Countries With High Levels of Global } \\
\text { Competitiveness - by Pillar - Among Countries with HIGH or LOW } \\
\text { Religious Hostilities or Government Restrictions on Religion }\end{array}$ \\
\hline $\begin{array}{l}\text { Primary education \& } \\
\text { health }\end{array}$ & $\begin{array}{l}\text { HIGH religious hostilities } \\
\text { LOW religious hostilities } \\
\text { HIGH govt. restrictions } \\
\text { LOW govt. restrictions }\end{array}$ & $\begin{array}{r}0 \% \\
16 \% \\
0 \% \\
16 \%\end{array}$ \\
\hline $\begin{array}{l}\text { Technical training \& } \\
\text { higher education }\end{array}$ & $\begin{array}{l}\text { HIGH religious hostilities } \\
\text { LOW religious hostilities } \\
\text { HIGH govt. restrictions } \\
\text { LOW govt. restrictions }\end{array}$ & $\begin{array}{r}0 \% \\
24 \% \\
0 \% \\
25 \%\end{array}$ \\
\hline $\begin{array}{l}\text { Technological } \\
\text { readiness }\end{array}$ & $\begin{array}{l}\text { HIGH religious hostilities } \\
\text { LOW religious hostilities } \\
\text { HIGH govt. restrictions } \\
\text { LOW govt. restrictions }\end{array}$ & $\begin{array}{r}8 \% \\
27 \% \\
0 \% \\
25 \%\end{array}$ \\
\hline Innovation & $\begin{array}{l}\text { HIGH religious hostilities } \\
\text { LOW religious hostilities } \\
\text { HIGH govt. restrictions } \\
\text { LOW govt. restrictions }\end{array}$ & $\begin{array}{r}8 \% \\
20 \% \\
7 \% \\
20 \%\end{array}$ \\
\hline $\begin{array}{l}\text { Communications \& } \\
\text { transport } \\
\text { infrastructure }\end{array}$ & $\begin{array}{l}\text { HIGH religious hostilities } \\
\text { LOW religious hostilities } \\
\text { HIGH govt. restrictions } \\
\text { LOW govt. restrictions }\end{array}$ & \begin{tabular}{r|r}
$0 \%$ & \\
$23 \%$ & \\
$7 \%$ & \\
$23 \%$ &
\end{tabular} \\
\hline $\begin{array}{l}\text { Market efficiency: } \\
\text { Goods }\end{array}$ & $\begin{array}{l}\text { HIGH religious hostilities } \\
\text { LOW religious hostilities } \\
\text { HIGH govt. restrictions } \\
\text { LOW govt. restrictions }\end{array}$ & $\begin{array}{r}0 \% \\
20 \% \\
7 \% \\
17 \%\end{array}$ \\
\hline $\begin{array}{l}\text { Business } \\
\text { sophistication }\end{array}$ & $\begin{array}{l}\text { HIGH religious hostilities } \\
\text { LOW religious hostilities } \\
\text { HIGH govt. restrictions } \\
\text { LOW govt. restrictions }\end{array}$ & $\begin{array}{r}8 \% \\
18 \% \\
7 \% \\
17 \%\end{array}$ \\
\hline $\begin{array}{l}\text { Financial market } \\
\text { development }\end{array}$ & $\begin{array}{l}\text { HIGH religious hostilities } \\
\text { LOW religious hostilities } \\
\text { HIGH govt. restrictions } \\
\text { LOW govt. restrictions }\end{array}$ & \begin{tabular}{r|}
$15 \%$ \\
$18 \%$ \\
$7 \%$ \\
$15 \%$
\end{tabular} \\
\hline $\begin{array}{l}\text { Institutional } \\
\text { environment } \\
\text { promoting wealth }\end{array}$ & $\begin{array}{l}\text { HIGH religious hostilities } \\
\text { LOW religious hostilities } \\
\text { HIGH govt. restrictions } \\
\text { LOW govt. restrictions }\end{array}$ & $\begin{array}{r}0 \% \\
24 \% \\
13 \% \\
19 \%\end{array}$ \\
\hline $\begin{array}{l}\text { Labor market } \\
\text { efficiency }\end{array}$ & $\begin{array}{l}\text { HIGH religious hostilities } \\
\text { LOW religious hostilities } \\
\text { HIGH govt. restrictions } \\
\text { LOW govt. restrictions }\end{array}$ & \begin{tabular}{r|}
$0 \%$ \\
$19 \%$ \\
$13 \%$ \\
$14 \%$
\end{tabular} \\
\hline Market size & $\begin{array}{l}\text { HIGH religious hostilities } \\
\text { LOW religious hostilities } \\
\text { HIGH govt. restrictions } \\
\text { LOW govt. restrictions }\end{array}$ & \begin{tabular}{l|}
$31 \%$ \\
$11 \%$ \\
$33 \%$ \\
$16 \%$
\end{tabular} \\
\hline $\begin{array}{l}\text { Macroeconomic } \\
\text { environment }\end{array}$ & $\begin{array}{l}\text { HIGH religious hostilities } \\
\text { LOW religious hostilities } \\
\text { HIGH govt. restrictions } \\
\text { LOW govt. restrictions }\end{array}$ & $\begin{array}{l}15 \% \\
18 \% \\
47 \% \\
11 \%\end{array}$ \\
\hline
\end{tabular}

* Strong is defined as 1.0 standard deviations above the mean of 148 countries on the World Economic Forum's Global Competitiveness Index's measures for each of the 12 pillars.

** High and Low categories of social hostilities involving religion or government restrictions on religion are as defined by the Pew Research Center's 2012 study, Social Hostilities Reach Six-Year High

Data: World Economic Forum Global Competitiveness Index (2013); Pew Research Center Government Restrictions on Religion Index and Social Hostilities Involving Religion Index (2012)

Рис. 2. Соотношение конкурентоспособности стран и уровня религиозных ограничений Примечание. Источник: [14]. 
Значительный рост государственных ограничений по отношению к религии и социальной нетерпимости в обществе социологи фиксируют в 2015 году. К 2017 г. ситуация не улучшилась, частота же и географическое разнообразие террористических атак подтверждают негативные тенденции. Число стран с высоким и очень высоким уровнем государственных ограничений религиозной свободы, что находит выражения в законодательных актах, политических решениях и действиях, акциях преследования по религиозному признаку, увеличилось с $24 \%$ в 2014 г. до 25 \% в 2015 году. Число стран с высоким уровнем социальной враждебности и религиозной нетерпимости по отношению к индивидуальным предпринимателям, религиозным организациям или группам в обществе повысилось с 23 \% в 2014 г. до 27 \% в 2015 году. Исследование показало, что в 2015 г. $40 \%$ стран вошло в разряд высокого и очень высокого уровня ограничений (2014 г. - 34 \%).

В 4 из 5 регионов, вошедших в поле исследования, зафиксировано увеличение показателей по государственным ограничениям религии и социальной нетерпимости: Европа, Ближний Восток, Северная Африка, Азия и Океания, Африка к югу от Сахары.

Из 198 стран 105 (53\%) - практиковали политику широких преследований религиозных групп (2014 г. $-43 \%)$.

Ограниченное преследование относительно определенных религиозных групп также увеличилось: в 2014 г. - в 44 странах (22\%); в 2015 г. - в 52 странах (26\%).

Государственное преследование и использование силы особенно резко выросло в Европе, где усилилась социальная вражда по отношению к мусульманскому населению [10] (рис. 3).

Европейское исследование ISPI позволило установить, что в 27 странах Европы $(60 \%)$ в 2015 г. практиковалось широкое распространенное преследование религиозных групп (в 2014 г. - 17 стран). А в 24 странах (53 \%) применяли силу против религиозных групп (в 2014 г. их число составляло 15$33 \%$ ). Франция и Россия среди европейских стран имели больше всех случаев использования государственной силы против религиозных групп - до 200 [15].

В 2015 г. почти 1,3 млрд беженцев прибыло в Европу в основном (54 \%) из трех мусуль- манских стран: Сирии, Афганистана, Ирака. Это фактически вдвое превышает число беженцев после распада СССР: в 1992 г. их число составляло 700 тысяч. Между тем социальная ненависть к христианам тоже увеличилась - с 17 стран в 2014 г. (38 \%) до 21 страны в 2015 г. (47 \%). Среди стран с наибольшим количеством населения Россия, Египет, Нигерия, Индия, Пакистан имеют самый высокий уровень государственных ограничений и социальной ненависти по религиозным причинам, причем в Египте самый высокий уровень государственных ограничений, в Нигерии - самый высокий уровень социальной нетерпимости [10].

\section{Europe sees largest increase in government harassment and use of force against religious groups}

$\%$ of countries in each region with increases in government harassment or use of force against religious groups between 2014 and 2015

\begin{tabular}{|c|c|}
\hline Europe & $\mathbf{5 3 \%}$ \\
\hline Sub-Saharan Africa & 48 \\
Americas & 37 \\
$\begin{array}{r}\text { Middle East- } \\
\text { North Africa }\end{array}$ & 30 \\
Asia-Pacific & 26
\end{tabular}

\section{$\%$ of countries in each region that experienced government harassment or use of force against religious groups in 2015}

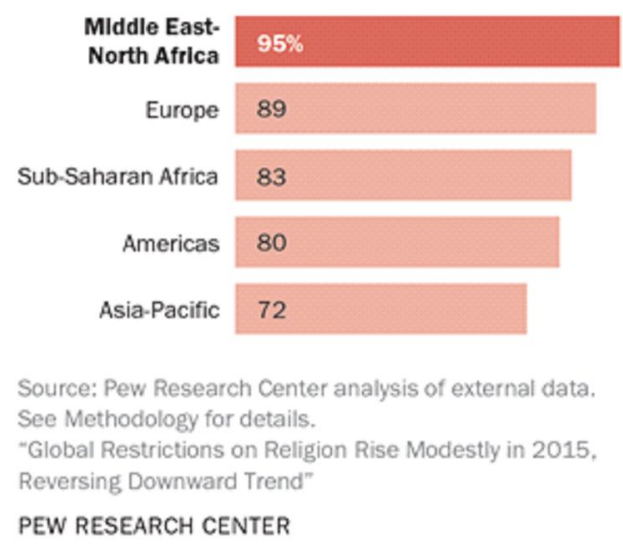

Рис. 3. Уровень правительственных преследований религиозных групп в 2015 г.

Примечание. Источник: [10].

Итак, глобальные ограничения религии усиливаются именно в 2015 году. Что это оз- 
начает? Может быть, пришел конец толерантности, так еще и не задышавшей в полную силу? Получается, что борьба за религиозную свободу обернулась своей обратной стороной - нетерпимостью одних верующих к другим? Тренд на усиление роли религии в публичной сфере в современном мире показывает явные амбивалентные последствия. В этом контексте заслуживает внимания недавняя интересная работа профессора Ноттингемского университета Дж. Милбанка и А. Пабста «The Politics of Virtue: Post-Liberalism and the Human Future» [11]. В этой книге авторы подчеркивают, что чем больше религия будет рассматриваться как угроза, тем меньше оснований для толерантности. Казалось бы, парадоксальный вывод на фоне страшных терактов под флагом религии. Разумеется, страх сковывает и людей, и государство. Вот и естественным следствием кажутся ограничения и применение силы. Но можно согласиться с авторами, что это односторонний подход к решению столь сложной задачи. Необходим диалог, поиск путей мирного сосуществования в религиозном многообразии, и особая роль отводится образованию и просвещению, религиозному образованию в частности.

К такому же выводу приходят исследователи ISPI: «В странах с высоким уровнем культурного и религиозного многообразия ограничения религиозной свободы являются контрпродуктивными в процессе создания социальной сплоченности и политического консенсуса. И на национальном, и на международном уровнях они достижимы только при усилении наших возможностей по защите индивидуального и коллективного права на религиозную свободу [15]. Это принципиально важно для современной России, в которой действуют почти 28 тысяч религиозных организаций 60 вероисповеданий. Исследования, проведенные Институтом социологии РАН в 2014-2016 гг. (проект «Динамика социальной трансформации современной России в социально-экономическом, политическом, социо- культурном и этнорелигиозном контекстах), позволяют сделать вывод о необходимости включения религиозного параметра в оценку политических процессов как основания, накладывающего отпечаток на «алгоритмы политических стратегий» [3, с. 133].

В июне 2015 - июле 2016 г. в 18 европейских странах исследовательским центром Pew Research Center проведено исследование «Религия и национальная принадлежность в Центральной и Восточной Европе» (Religious Belief and National Belonging in Central and Eastern Europe. National and religious identities converge in a region once dominated by atheist regimes) [13].

На основании проведенного исследования религиозный портрет России выглядит следующим образом (табл. 1).

Религиозный состав населения стран Центральной и Восточной Европы представлен в таблице 2.

Исследование показало, что доля воцерковленных христиан (посещающих коллективное богослужение еженедельно, соблюдающих религиозные правила и ограничения, знающих Священное Писание) невелика и составляет в среднем по региону Центральной и Восточной Европы $10 \%$. В то же время в странах с преимущественно православным населением выявлена тесная связь между религиозной и национальной идентичностью. Жители этих стран считают, что православие является важной составляющей национальной идентичности. В Армении это признали $82 \%$ респондентов, в Грузии - $81 \%$, Сербии - $78 \%$, Греции $-76 \%$, Румынии - $74 \%$, Болгарии $66 \%$, Молдавии - $63 \%$, России - $57 \%$, Украины - $51 \%$, Белоруссии - $45 \%$. Медиана для этих стран составляет $70 \%$. В странах с преимущественно католическим населением медиана составляет 57 \% (в частности, во Франции роль католицизма в формировании национальной идентичности признали $23 \%$ респондентов, в Германии - $30 \%$ ).

Кроме того, респонденты, проживающие в православных странах, более склонны считать,

Таблийа 1

Религиозный портрет России

\begin{tabular}{|l|c|c|c|c|c|}
\hline & Православие & Католицизм & Ислам & Неверующие & $\begin{array}{c}\text { Не определившиеся } \\
\text { (ответ «не знаю») }\end{array}$ \\
\hline $\begin{array}{l}\text { Количество по- } \\
\text { следователей (\%) }\end{array}$ & 71 & 1 & 10 & 15 & 4 \\
\hline
\end{tabular}


Е.М. Мирошникова,О.И. Сгибнева. Религиозная политика светского государства

Таблица 2

\section{Религиозный состав населения стран Центральной и Восточной Европы}

\begin{tabular}{|c|c|c|c|c|c|}
\hline $\begin{array}{c}\text { № } \\
\text { ח/ח }\end{array}$ & Страны & Православие & Католицизм & Другие религии & Никакой религии \\
\hline \multicolumn{6}{|c|}{ Страны с доминирующим православием } \\
\hline 1 & Молдова & 92 & 2 & 6 & \\
\hline 2 & Греция & 90 & 2 & 4 & 4 \\
\hline 3 & Армения & 89 & 2 & 7 & \\
\hline 4 & Грузия & 89 & & 9 & \\
\hline 5 & Сербия & 88 & 4 & 4 & 2 \\
\hline 6 & Румыния & 86 & 5 & 8 & \\
\hline 7 & Украина & 78 & & & \\
\hline 8 & Болгария & 75 & & & \\
\hline 9 & Беларусь & 73 & & & \\
\hline 10 & Россия & 71 & & & \\
\hline \multicolumn{6}{|c|}{ Страны с доминирующим католическим населением } \\
\hline 1 & Польша & & 87 & & \\
\hline 2 & Хорватия & & 84 & & \\
\hline 3 & Литва & & 75 & & \\
\hline 4 & Венгрия & & 56 & & \\
\hline \multicolumn{6}{|c|}{ Страны без доминирующих религий } \\
\hline 1 & Эстония & 25 & & 29 & 45 \\
\hline 2 & Босния & 35 & 8 & 52 (ислам) & 3 \\
\hline 3 & Латвия & 31 & 32 & 25 & 21 \\
\hline \multicolumn{6}{|c|}{ Большинство населения неверующие } \\
\hline 1 & Чехия & & 21 & 6 & 72 \\
\hline
\end{tabular}

что их культура превосходит все остальные. Большинство населения стран с православной религиозной ориентацией признает авторитет России и Русской православной церкви (Московский патриархат) и считают, что Россия должна противостоять Западу: медиана по всем странам исследуемого региона - 52, в странах с преимущественно православным населением 66, в странах с преимущественно католическим населением - 42. Значительное большинство респондентов в православных странах ставит авторитет Патриарха Московского и Всея Руси выше Константинопольского Патриарха и признают лидерство Русской православной церкви (МП) среди автокефальных церквей [13] (см. рис. 4). В европейской части России $72 \%$ опрошенных считают, что их страна имеет нравственные обяза- тельства по защите православных христиан в других странах.

Отношение населения к поддержке религии государством представлено в таблице 3 .

Наиболее активно поддерживают государственное участие в распространении религиозных ценностей в Армении (59\%), Литве $(43 \%)$ и России (42\%).

В православных странах более всего рассчитывают на финансовую поддержку религиозных организаций в Грузии $(82 \%)$, в России на это надеятся $50 \%$ респондентов. В католических странах на финансовую помощь конфессий уповает меньшее число респондентов: в Литве - $42 \%$, Венгрии - $41 \%$, Хорватии - $40 \%$, Польше $28 \%[13]$.

Таблицьа 3

Отношение населения стран Центральной и Восточной Европы к поддержке религии государством

\begin{tabular}{|l|c|c|}
\hline \multicolumn{1}{|c|}{ Страны } & $\begin{array}{c}\text { Государство должно под- } \\
\text { держивать распространение } \\
\text { религиозных ценностей (\%) }\end{array}$ & $\begin{array}{c}\text { Государство должно оказывать } \\
\text { финансовую поддержку } \\
\text { религиозным организациям (\%) }\end{array}$ \\
\hline Все страны региона & 36 & 44 \\
\hline $\begin{array}{l}\text { Страны с преимущественно } \\
\text { православным населением }\end{array}$ & 42 & 56 \\
\hline $\begin{array}{l}\text { Страны с преимущественно } \\
\text { католическим населением }\end{array}$ & 28 & 41 \\
\hline
\end{tabular}




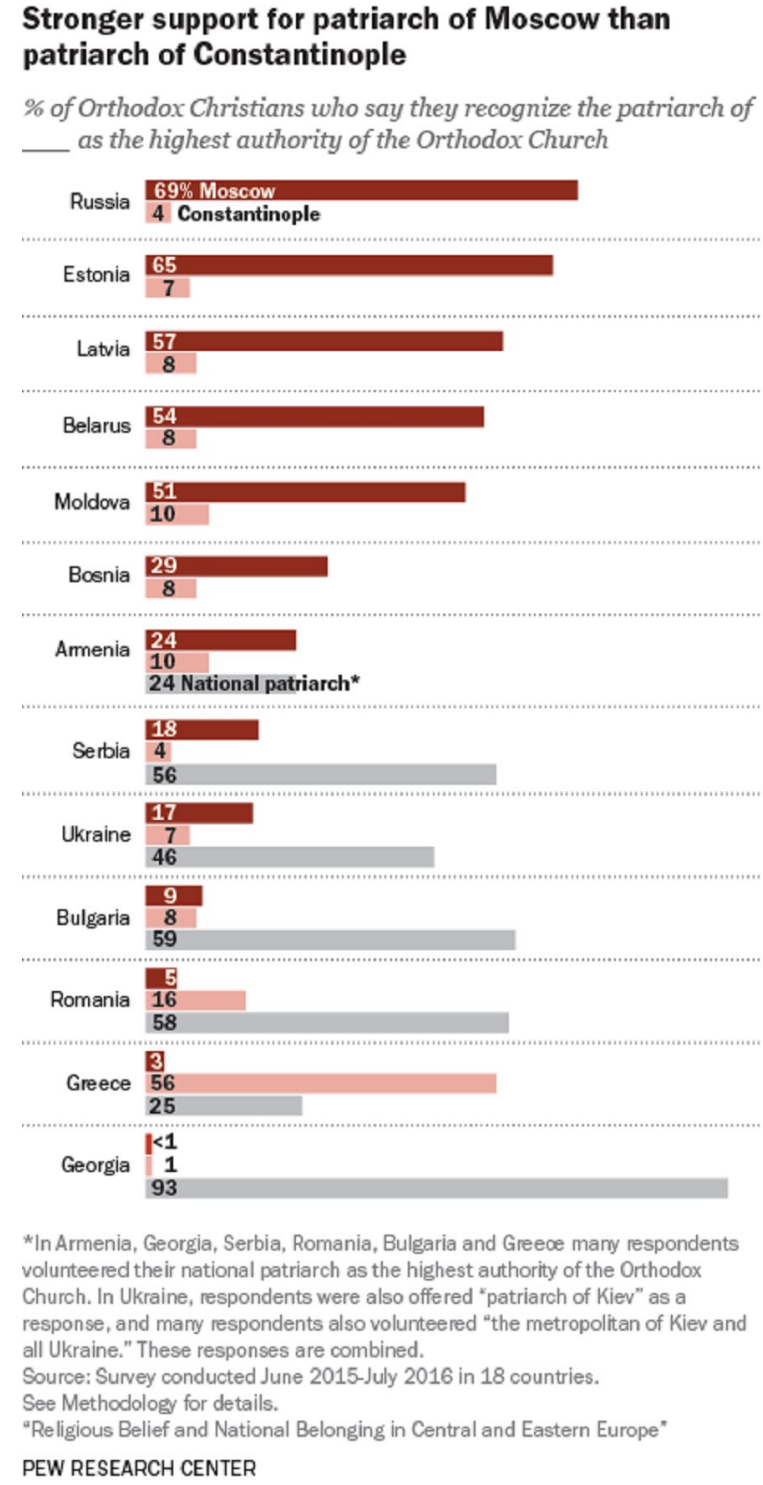

Рис. 4. Соотношение уровня поддержки Московского патриархата и Константинопольского патриархата

Примечание. Источник: [13].

Анализ результатов исследований, проведенных Pew Research Center и Italian Institute for International Political Studies (ISPI), показывает, что в обострении социально-политических противоречий в европейских странах значительную роль сыграл религиозный фактор. В то же время ограничение религиозной свободы и применение государством силы в решении конфликтов на религиозной почве не способствуют преодолению противоречий. Опыт европейских стран актуализирует проблему разработки государственной политики в сфере государственно-конфессиональных и межрелигиозных отно- шений, основанной на принципах свободы совести и свободы вероисповеданий как важного инструмента реализации стратегии национальной безопасности Российской Федерации, укрепления авторитета страны на международной арене, сохранения единства народов России. Это тем более важно, что позиции Русской православной церкви усиливаются как внутри страны, так и за рубежом, потому увеличивается ее присутствие в жизни и общества, и государства, а следовательно возникает опасность, что они могут выйти из правового поля.

В России впервые в истории реализуется право человека на свободу совести в условиях отсутствия государственной церкви и равенства всех религий перед законом. В результате, естественно, возникают серьезные правовые коллизии, желание быстрее решить сложные проблемы, подменить законность целесообразностью. Государству пока трудно свыкнуться с тем, чтобы не вмешиваться в деятельность религиозных объединений или отказаться от роли арбитра в истинности той или иной веры. Для религиозного объединения реальная возможность церковной свободы питает желание включаться в решение широкого круга социальных светских проектов и программ... На фоне дефицита толерантности все чаще звучат призывы к установлению единой государственной идеологии. Ситуация обостряется глобализационными процессами, в ответ на которые государство стремится использовать наиболее влиятельные в России религии для сохранения единого культурного пространства и территориальной целостности России [2, c. 65]. Не случайно в Основах государственной культурной политики, утвержденных Указом Президента РФ № 808 от 24 декабря 2014 г., подчеркивается, что традиционные для нашего Отечества религии - православие, ислам, иудаизм, другиерелигии и верования внесли свой вклад в формирование национально-культурного самосознания народов; ни вероисповедание, ни национальность не разделяют и не должны разделять народы России [8, с. 2-3].

Важным фактором гармонизации отношений в религиозной сфере является кадровое обеспечение тех государственных структур, которые участвуют в реализации политики в области государственно-конфессиональных отношений. Сегодня особенно остро стоит эта проблема на местах, в регионах и му- 
ниципалитетах. Одним из механизмов ее решения должен стать новый профессиональный стандарт «Специалист в сфере межнациональных и межрелигиозных отношений». Заключительный этап его обсуждения на заседании круглого стола «Специалист в сфере межнациональных и межрелигиозных отношений: вызовы времени и профессиональный стандарт» в РАНХиГС при Президенте Российской Федерации 8 июня 2017 г. еще раз показал необходимость и востребованность профессионалов в этой области. Нуждается в совершенствовании и система религиоведческой подготовки в целом. Сегодня знания по истории и теории религии становятся необходимыми для специалистов самых разных направлений: журналистов и юристов, политологов, педагогов, психологов, социологов, лингвистов. И вся эта работа должна стать составной частью общегосударственной стратегии религиозной политики в России.

\section{ПРИМЕЧАНИЯ}

1 Общероссийская общественная организация «Российская ассоциация защиты религиозной свободы» (РАРС) зарегистрирована Минюстом России 28 ноября 2014 года. Ее учредителями и членами являются представители Русской православной церкви, Русской православной старообрядческой церкви, Римско-католической церкви, мусульманских религиозных организаций, Буддистской традиционной сангхи России, Федерации еврейских общин России, Ново-Нахичеванской Российской епархии Армянской апостольской церкви, Евангелическо-лютеранской Церкви, Церкви христиан-адвентистов Седьмого Дня, Российского объединенного союза христиан веры евангельской, Российской церкви христиан веры евангельской, а также ученые-религиоведы и правозащитники. При этом РАРС - конфессионально и политически нейтральная организация. Все решения и рекомендации согласно Уставу организации принимаются на основе консенсуса. Руководящим органом РАРС является Совет Ассоциации.

2 Перевод материалов социологических исследований с английского языка осуществлен Е.М. Мирошниковой.

\section{СПИСОК ЛИТЕРАТУРЫ}

1. Конституция Российской Федерации. - М. : Норма, 2003. - 160 c.
2. Мирошникова, Е. М. Особенности государственной политики в области свободы совести / Е. М. Мирошникова // Вестник Нижегородской правовой академии : науч. журн. - 2015. - № 6. - С. 65-72.

3. Мчедлова, М. М. Религия между традицией и современностью: российский контекст / М. М. Мчедлова // Роль религии в современном мире : материалы науч.-практ. конф., Москва, 2016 г. - М. : РAРC, 2016. - С. 133-146.

4. Покидова, В. РПЦ встала на защиту закона о свободе совести и вероисповедания / В. Покидова. - Электрон. текстовые дан. - Режим доступа: https://polit.info/359364-rpc-vstala-na-zashchituzakona-o-svobode-sovesti-o-veroispovedaniya (дата обращения: 18.10.2017). - Загл. с экрана.

5. Свобода совести и религиозная нетерпимость в современном мире / РАРС. - М. : Юрист, 2017. $-144 \mathrm{c}$.

6. Сгибнева, О. И. Отношения государства и религиозных организаций в условиях свободы совести / О. И. Сгибнева // Вестник ВолГУ. Серия 7, Философия. Социология и социальные технологии. -2012. - № 1 (1). - С. 99-104.

7. Стратегия государственной национальной политики в Российской Федерации на период до 2025 г. - Электрон. текстовые дан. - Режим доступа: http://static.kremlin.ru/media/acts/files/0001201 212190001.pdf(дата обращения: 25.10.20017). - Загл. с экрана.

8. Указ Президента РФ от 24.12.2014 № 808 «Об утверждении Основ государственной культурной политики». - Электрон. текстовые дан. - Режим доступа: http://www.consultant.ru/document/cons doc_LAW_172706(дата обращения: 12.11.2017). -Загл. с экрана.

9. Федеральный закон «О свободе совести и о религиозных объединениях». - 2-е изд. - М. : Ось89, 2008. -32 c.

10. Global Restrictions on Religion Rise Modestly in 2015, Reversing Downward Trend. - Electronic text data. - Mode of access: http://religiousfreedomand business.org/2/post/2017/08/charlottesville-violencehighlights-high-religious-hostilities-in-u-s-and-world. html (data of access: 14.09.2017) ; http://www. pewforum.org/2017/04/11/global-restrictions-onreligion-rise-modestly-in-2015-reversing-downwardtrend (data of access: 30.10.2017). - Title from screen.

11. Milbank, J. The Politics of Virtue: Postliberalism and the Human Future. Future Perfect: Images of the Time to Come in Philosophy, Politics and Cultural Studies / J. Milbank, A. Pabst. - London : Rowman \& Littlefield International, 2016. - 385 p.

12. Religion and the secular State: National Reports / Javier Martinez-Torron, W. Cole Durham, Jr. (General Reporters), Donlu D.Thayler (ed.). - Madrid : Complutense Universidad de Madrid, 2015. - 898 p. 
13. Religious Beliefand National Belonging in Central and Eastern Europe. - Electronic text data. - Mode of access: http://www.pewforum.org/2017/05/10/religiousbelief-and-national-belonging-in-central-and-easterneurope (data of access: 10.09.2017). - Title from screen.

14. Grim, B. J. Is Religious Freedom Good for Business?: A Conceptual and Empirical Analysis / B. J. Grim, C. Greg, R. E. Snyder // Interdisciplinary Journal of Research on Religion. - 2014. - Vol. 10.Electronic text data. - Mode of access: http://www. religjournal.com/pdf/ijrr10004.pdf (data of access: 15.10.2017). - Title from screen.

15. Promoting Religious Freedom and Peace through Cross-Cultural Dialogue based on the International Workshop with academia, think tank and media representatives held on 11 February 2013 at the Italian Ministry of Foreign Affairs, Rome authored by Silvio Ferrari and Fabio Petito. - Electronic text data. Mode of access: http:/www.ispionline.it/sites/default/ files/pubblicazioni/ispi_report31_10_2013.pdf(data of access: 19.09 .2017$).-\bar{T}$ Title from screen.

\section{REFERENCES}

1. Konstitutsiya Rossiyskoy Federatsii [The Constitution of the Russian Federation]. Moscow, Norma Publ., 2003. 160 p.

2. Miroshnikova E.M. Osobennosti gosudarstvennoy politiki v oblasti svobody sovesti [Features of State Policy in the Freedom of Conscience]. Vestnik Nizhegorodskoy pravovoy akademii: nauch. zhurn., 2015, no. 6, pp.65-72.

3. Mchedlova M.M. Religiya mezhdu traditsiey i sovremennostyu: rossiyskiy kontekst [Religion Between Tradition and the Modernity: the Russian Context]. Rol religii v sovremennom mire: materialy nauch.-prakt. konf., Moskva, 2016 g. [The Role of Religion in the Modern World. Proceedings of Research and Practice Conference, Moscow, 2016]. Moscow, RARS Publ., 2016, pp. 133-146.

4. Pokidova V. RPTs vstala na zashchitu zakona o svode sovesti $i$ veroispovedaniya [The Russian Orthodox Church Rallied to Protection of Law on Conscience and confession]. URL: https://polit.info/359364-rpc- vstalana-zash chitu-zakona-o-svobode-sovesti-overoispovedaniya (accessed October 18, 2017).

5. Svoboda sovesti i religioznaya neterpimost v sovremennom mire [The Freedom of Conscience and Religious Intolerance in the Modern World]. Moscow, Yurist Publ., 2017. 144 p.

6. Sgibneva O.I. Otnosheniya gosudarstva i religioznykh organizatsiy $\mathrm{v}$ usloviyakh svobody sovesti [Attitudes of State and Religious Organizations in the Conditions of the Freedom of Conscience]. Vestnik Volgogradskogo gosudarstvennogo universiteta. Seriya 7, Filosofiya. Sotsiologiya $i$ sotsialnye tekhnologii [Science Journal of Volgograd State University. Philosophy. Sociology and Social Technologies], 2012, vol. 1 (16), pp. 99-104.

7. Strategiya gosudarstvennoy natsionalnoy politiki v Rossiyskoy Federatsii na period do $2025 \mathrm{~g}$. [Strategy of the State National Policy in the Russian Federation for the Period Till 2025]. URL: static. kremlin.ru/media/acts/files/0001201212190001.pdf (accessed October 25, 2017).

8. Ukaz Prezidenta RF ot 24.12.2014 № 808 «Ob utverzhdenii Osnov gosudarstvennoy kulturnoy politiki» [The Decree of the President of the Russian Federation of December 24, 2014 no. 808 "On Approving the Bases of State Cultural Policy"]. URL: http://www.consultant.ru/document/cons_doc_ LAW_172706 (accessed November 12, 2017).

9. Federalnyy zakon "O svobode sovesti $i o$ religioznykh obyedineniyakh» [The Federal Law “On the Freedom of Conscience and on Religious Associations"]. Moscow, Os-89 Publ., 2008. 32 p.

10. Global Restrictions on Religion Rise Modestly in 2015, Reversing Downward Trend. URL: http:// religiousfreedomandbusiness.org/2/post/2017/08/ charlottesville-violence-highlights-high-religioushostilities-in-u-s-and-world.html. (accessed September 14, 2017); http://www.pewforum.org/2017/04/11/globalrestrictions-on-religion-rise-modestly-in-2015-reversingdownward-trend/ (accessed October 30, 2017).

11. Milbank J., Pabst A. The Politics of Virtue: Post-liberalism and the Human Future. Future Perfect: Images of the Time to Come in Philosophy, Politics and Cultural Studies. London, Rowman \& Littlefield International, 2016. 385 p.

12. Martinez-Torron J., Durham W.C., Thayler D.D. Religion and the secular State: National Reports. Madrid, Complutense Universidad de Madrid, 2015. 898 p.

13. Religious Belief and National Belonging in Central and Eastern Europe. URL: http://www. pewforum.org/2017/05/10/religious-belief-andnational-belonging-in-central-and-eastern-europe (accessed September 10, 2017).

14. Grim B.J., Greg C., Snyder R.E. Is Religious Freedom Good for Business? A Conceptual and Empirical Analysis. Interdisciplinary Journal of Research on Religion, 2014, vol. 10. URL: http:// www.religjournal.com/pdf/ijrr10004.pdf (accessed October 15, 2017).

15. Ferrari S., Petito F., eds. Promoting Religious Freedom and Peace through Cross-Cultural Dialogue based on the International Workshop with academia, think tank and media representatives held on 11 February 2013 at the Italian Ministry of Foreign Affairs. URL: http://www.ispionline.it/sites/ default/files/pubblicazioni/ispi_report31_10_2013.pdf (accessed September 19, 2017). 


\section{Information about the Authors}

Elena M. Miroshnikova, Doctor of Philosophical Sciences, Professor, Chief Researcher, Research Center for Cultural and Religious Studies, Leningrad State University named after A.S. Pushkin, Peterburgskoe shosse, 10, 196605 Saint Petersburg, Russian Federation, miroshnikovaem@gmail.com.

Olga I. Sgibneva, Doctor of Philosophical Sciences, Professor, Department of Sociology, Volgograd State University, Prosp. Universitetsky, 100, 400062 Volgograd, Russian Federation, olga.sgibneva@volsu.ru.

\section{Информация об авторах}

Елена Михайловна Мирошникова, доктор философских наук, профессор, главный научный сотрудник Научно-исследовательского центра культурологических и религиоведческих исследований, Ленинградский государственный университет им. А.С. Пушкина, Петербургское шоссе, 10, 196605 г. Санкт-Петербург, Российская Федерация, miroshnikovaem@gmail.com.

Ольга Ивановна Сгибнева, доктор философских наук, профессор кафедры социологии, Волгоградский государственный университет, просп. Университетский, 100, 400062 г. Волгоград, Российская Федерация, olga.sgibneva@volsu.ru. 